\title{
Mengevaluasi Efektivitas Pelaksanaan Program Kota Tanpa Kumuh (Studi Kasus pada Wilayah Kota Langsa)
}

\author{
Evaluating the Effectiveness of the Implementation of \\ City Without Slum Program (Case Study in Langsa City Area)
}

\author{
Safrizal Safrizal $^{1)}$, Safuridar Safuridar ${ }^{2)}$, Muhammad Fuad ${ }^{3)}$ \\ ${ }^{1,2,3)}$ Fakultas Ekonomi, Universitas Samudra, Kota Langsa \\ e-mail korespondensi: muhammadfuad@unsam.ac.id
}

\begin{tabular}{|l|}
\hline Info Artikel \\
\hline Riwayat Artikel : \\
Diterima: 05 Februari 2021 \\
Disetujui: 26 April 2021 \\
Dipublikasikan: Juli 2021 \\
\hline Nomor DOI \\
10.33059/jseb.v12i2.3242 \\
Cara Mensitasi : \\
Safrizal, S., Safuridar, S., \& \\
Fuad, M. (2021). \\
Mengevaluasi efektivitas \\
pelaksanaan program kota \\
tanpa kumuh (Studi kasus \\
pada wilayah Kota Langsa). \\
Jurnal Samudra Ekonomi dan \\
Bisnis, 12(2), 200-213. doi: \\
10.33059/jseb.v12i2.3242. \\
\end{tabular}

\begin{abstract}
Abstrak
Pertumbuhan dan perkembangan penduduk bisa menimbulkan ekses bagi munculnya kawasan permukiman kumuh, yang sering dilihat sebagai sesuatu yang potensial menimbulkan masalah di perkotaan. Untuk mengurangi permasalahan perumahan dan kawasan kumuh tersebut, salah satu program pemerintah adalah Program Kota Tanpa Kumuh (KOTAKU). Penelitian ini bertujuan untuk menganalisis efektifitas program KOTAKU di Kota Langsa, serta mengidentifikasi faktor-faktor penghambat dari program ini. Responden penelitian adalah seluruh kepala desa di Kota Langsa, anggota masyarakat yang terlibat langsung maupun tidak langsung dalam program KOTAKU, serta pemangku kepentingan lainnya, dengan total jumlah 166 orang responden. Data primer dikumpulkan melalui instrumen kuesioner. Evaluasi efektivitas dihitung menggunakan nilai rerata secara persentase dari setiap indikator. Hasil analisis data menemukan bahwa program KOTAKU dinilai sudah efektif sebagai upaya mengurangi pemukiman kumuh di Kota Langsa. Namun demikian, teridentifkasi beberapa faktor yang menjadi penghambat utama dalam pelaksanaan program tersebut.
\end{abstract}

Kata Kunci: Efektivitas, Program KOTAKU, Kota Langsa.

\begin{tabular}{|c|c|}
\hline & Abstract \\
\hline $\begin{array}{l}\text { Artict } \\
\text { Recei } \\
\text { Acce } \\
\text { Publi }\end{array}$ & $\begin{array}{l}\text { Population growth and development can lead to excesses for the emergence of } \\
\text { slum areas, which are often seen as a potential problem in urban areas. To } \\
\text { reduce the problems of housing and slum areas, one of the government } \\
\text { programs is the City Without Slum (in Indonesia called KOTAKU) program. }\end{array}$ \\
\hline $\begin{array}{l}\text { DOI } \\
10.33 \\
\text { How } \\
\text { Safriz } \\
\text { Fuad, } \\
\text { Meng } \\
\text { pelaks } \\
\text { tanpa } \\
\text { pada }\end{array}$ & $\begin{array}{l}\text { This study aims to analyze the effectiveness of the program in Langsa City and } \\
\text { identify the inhibiting factors of this program. } 166 \text { respondents were all village } \\
\text { chiefs in Langsa City, community members who were directly or indirectly } \\
\text { involved in the program, as well as other stakeholders. Primary data were } \\
\text { collected through a questionnaire. The effectiveness evaluation is calculated } \\
\text { using the mean value as a percentage of each indicator. The results found that } \\
\text { the KOTAKU program was considered effective as an effort to reduce slum } \\
\text { settlements in Langsa City. However, several factors were identified that were } \\
\text { the main obstacles in the implementation of the program. }\end{array}$ \\
\hline
\end{tabular}

Bisnis, 12(2), 200-213. doi:

10.33059/jseb.v12i2.3242.

Keywords: Effectiveness, KOTAKU Program, Langsa City. 


\section{PENDAHULUAN}

Adanya pembangunan suatu daerah menyebabkan terjadinya pertumbuhan serta perkembangan penduduk yang pesat dan memiliki dampak terhadap sejumlah aspek, khususnya ketersediaan sarana serta prasarana bersifat mendasar yang saling menyusul dengan tingkat laju pertumbuhan penduduk. Pertumbuhan penduduk ini bisa menimbulkan ekses bagi munculnya kawasan permukiman kumuh, yang sering dilihat sebagai sesuatu yang potensial menimbulkan masalah pada area perkotaan.

UU Nomor 1 Tahun 2011 mengenai Perumahan dan Kawasan Permukiman menjelaskan bahwa permukiman kumuh adalah tipe permukiman yang dinilai tidak layak huni akibat ada kondisi ketidakteraturan bangunan, tingginya derajat kepadatan bangunan, serta kualitas bangunan serta sarana dan prasarana yang tidak memenuhi syarat; sedangkan Perumahan Kumuh merupakan perumahan yang mengalami degradasi kualitas fungsi sebagai tempat hunian. Salah satu upaya yang gencar dilakukan oleh pemerintah untuk menangani kondisi kumuh yaitu upaya meningkatkan derajat kualitas perumahan serta permukiman kumuh guna mempertinggi mutu kehidupan dan penghidupan masyarakat (Brelsford et al., 2018; Sari, 2018).

Untuk mengurangi permasalahan dari area perumahan dan kawasan kumuh itu, pemerintah meluncurkan program yang dinamakan Program Kota Tanpa Kumuh (KOTAKU). Program ini adalah salah satu andalan dari Kementerian Pekerjaan Umum dan Perumahan Rakyat (PUPR), yang dalam hal ini dilaksanakan oleh Direktorat Jenderal Cipta Karya. Informasi tentang program ini dinyatakan dalam website milik KOTAKU (http://kotaku.pu.go.id) dengan tujuan umum adalah meningkatkan akses atas infrastruktur dan pelayanan dasar di kawasan kumuh perkotaan untuk mendukung terwujudnya permukiman perkotaan layak huni, produktif dan berkelanjutan.

Pada tujuan umum itu terkandung dua maksud. Maksud pertama yaitu memperbaiki akses masyarakat terhadap infrastruktur serta fasilitas pelayanan di permukiman kumuh perkotaan. Maksud kedua yaitu meningkatkan kesejahteraan masyarakat di area perkotaan melalui pencegahan dan peningkatan derajat kualitas permukiman kumuh, dengan berbasis masyarakat, serta partisipasi dari pemerintah daerah. Program ini mendukung "Gerakan 100-0-100", yaitu 100 persen akses universal atas air minum, 0 persen permukiman kumuh, serta 100 persen akses atas sanitasi layak (http://kotaku.pu.go.id).

Program KOTAKU telah dilaksanakan di Kota Langsa sejak tahun 2016, berdasarkan SK Walikota No. 324/413/2016. Program ini tersebar di lima kecamatan dan 66 desa, dengan total luas dari kawasan kumuh di Kota Langsa mencapai 89.235 Ha. Dari total desa yang termasuk dalam SK Walikota tersebut, lima desa ditetapkan sebagai desa penanganan kumuh, sementara desa lainnya dimasukkan dalam kategori pencegahan.

Hasil penelusuran awal peneliti melalui wawancara dengan pihak pengelola program KOTAKU baik bersifat online maupun offline, belum ditemukan hasil riset akademis mengenai penilaian efektifitas dari program KOTAKU di Kota Langsa. Karenanya penelitian ini diekspektasikan memperoleh hasil-hasil yang bermanfaat sebagai referensi dasar mengenai tingkat efektifitas program tersebut di Kota Langsa. Hal ini dinilai sangat krusial karena derajat efektivitas suatu program penting untuk dievaluasi secara berkelanjutan agar bisa diidentifikasi kendala ataupun kelemahan yang dihadapi selama pelaksanaan program tersebut.

Berdasarkan latar belakang tersebut, maka ada dua rumusan masalah utama yang ingin dibahas. Masalah pertama adalah untuk 
mengidentifikasi apakah program KOTAKU yang dilaksanakan di Kota Langsa sudah berjalan dengan efektif atau belum sesuai dengan yang diharapkan Masalah kedua adalah berupaya memperdalam faktor-faktor yang menjadi penghambat dalam pelaksanaan program KOTAKU di Kota Langsa.

\section{Pengertian dan Standar Pengukuran Efektifitas}

Efektifitas memiliki kata dasar "efektif" yang berasal dari bahasa Inggris yaitu "effective" atau sesuatu yang dilakukan bisa berhasil baik. Beberapa peneliti menyatakan efektivitas merupakan hubungan antara output dengan pencapaian tujuan, dimana apabila kontribusi output semakin besar terhadap pencapaian tujuan suatu kegiatan ataupun program, maka pelaksanaan kegiatan atau program tersebut dinyatakan semakin efektif (Sudriamunawar, 2012; Cribbin, 2010; Satries, 2011).

Efektifitas adalah proses komunikasi bagi pencapaian tujuan yang direncanakan sesuai anggaran biaya, skedul waktu dan jumlah personil yang ditentukan (Daft, 2012; Steers, 2005; Anggara \& Sumatri, 2016). Efektifitas berfokus pada output suatu kegiatan yang dicapai berdasar-kan batasan anggaran biaya, skedul waktu dan jumlah personil yang ada; dimana apabila output yang dihasilkan semakin memenuhi atau melebihi tujuan yang ingin dicapai, maka pelaksanaan program dinilai semakin efektif (Alam et al., 2017; Garcia-Sanchez et al., 2013; Mihaiu et al., 2010).

Variabel-variabel yang bisa digunakan sebagai standar pengukuran untuk menilai apakah pencapaian tujuan telah terlaksana secara efektif atau tidak dikemukakan oleh sejumlah peneliti. Budiani (2009) menyatakan empat standar efektivitas, yaitu: (1) ketepatan sasaran program; (2) sosialiasi program; (3) tujuan program; serta, (4) pemantauan program. Karauwan et al. (2017) menyatakan lima ukuran efektivitas, yaitu: (1) produksi; (2) efisiensi; (3) kepuasan; (4) adaptasi; dan (5) pengembangan. Selanjutnya, Siagian (2014) menyatakan tujuh ukuran efektivitas meliputi: (1) kejelasan tujuan yang ingin dicapai; (2) kejelasan strategi bagi pencapaian tujuan; (3) kemantapan proses analisis serta perumusan kebijakan; (4) kematangan proses perencanaan; (5) ketepatan dari penyesuaian program; (6) tersedianya fasilitas sarana dan prasarana kerja; serta (7) proses pelaksanaan program secara efektif dan efisien.

Dalam penelitian ini, standar ukuran dari efektifitas mengarah pada harus adanya perbandingan di antara input dan output. Pengukuran efektivitas dalam penelitian ini mengarah kepada perspektif masyarakat terhadap pelaksanaan program KOTAKU, yang diperoleh melalui instrumen kuesioner dan wawancara mendalam, dan didukung hasil observasi dan evaluasi data sekunder.

\section{Program KOTAKU}

Program KOTAKU atau Kota Tanpa Kumuh merupakan program yang dijalankan secara nasional di 271 Kabupaten/Kota pada 34 Propinsi; dan menjadi basis penanganan pemukiman kumuh melalui pengintegrasian berbagai sumber daya maupun sumber pendanaan, baik dari Pemerintah Pusat, Pemerintah Daerah Kabupaten/Kota, institusi pendonor, swasta, masyarakat, serta para stakeholder lain. Program ini disosialisasikan awal oleh Direktur Cipta Karya Kementerian PUPR tanggal 26 April 2016, selanjutnya tiap pemerintah daerah melakukan sosialisasi pada wilayahnya masing-masing.

Program KOTAKU adalah kelanjutan dari program PNPM Mandiri Perkotaan sebelumnya. Perbedaan keduanya adalah pada tujuan (objectives) dimana program PNPMMP memiliki tujuan peningkatan akses sosial bagi masyarakat miskin serta memenuhi 
kebutuhan dari masyarakat miskin; sementara program KOTAKU bertujuan mencegah dan menangani area pemukiman kumuh. Namun tujuan akhir keduanya pada masyarakat miskin adalah serupa, yaitu peningkatan kehidupan sosial serta ekonomi masyarakat miskin (Pedoman KOTAKU, 2016). Tujuan program KOTAKU adalah peningkatan akses masyarakat di pemukiman kumuh terhadap infrastruktur dan pelayanan dasar perkotaan dalam mendukung terciptanya pemukiman kota layak huni, produktif dan berkelanjutan. Pencapaian output program ini berkontribusi atas tercapainya sasaran dari Rencana Pembangunan Jangka Menengah Nasional (RPJMN) 2015-2019 berupa pengentasan wilayah pemukiman kumuh perkotaan menjadi sebesar 0 (nol) persen (Pedoman KOTAKU, 2016).

Output dari program KOTAKU adalah meningkatnya akses masyarakat terhadap infrastruktur serta pelayanan perkotaan pada pemukiman kumuh (seperti adanya drainase, air bersih atau minum, pengelolaan sampah, pengamanan kebakaran, serta ruang terbuka publik), penurunan luasan pemukiman kumuh sebagai hasil dari ketersediaan akses tersebut, berfungsinya kelembagaan Pokja PKP pada tingkat Kabupaten/Kota dalam mendukung program ini, adanya kepuasan penerima manfaat atas kualitas dari infrastruktur dan pelayanan perkotaan serta meningkatnya kesejahteraan dan penghidupan berkelanjutan dari masyarakat di pemukiman kumuh (Pedoman KOTAKU, 2016).

\section{Telaah Riset tentang Efektifitas Program KOTAKU}

Sejumlah penelitian terdahulu yang tersebar di beberapa daerah telah dilakukan untuk mengukur derajat peran atau efektivitas dari program KOTAKU terhadap daerah yang menjadi lokasi penelitian. Hasil beragam ditemukan oleh para peneliti terdahulu itu dalam menilai efektivitas program tersebut.

Studi Zuhrya (2017) yang melakukan deskripsi atas implementasi dan kendala dalam pelaksanaan program KOTAKU dalam memberdayakan ekonomi masyarakat. Studi ini dilakukan pada Desa Putih Kecamatan Gampengrejo Kabupaten Kediri, menggunakan pendekatan kualitatif melalui metode wawancara, observasi dan dokumentasi. Hasil penelitian memperoleh bahwa implementasi program KOTAKU dinilai telah melibatkan partisipasi masyarakat, mulai dari proses perencanaan sampai pelaksanaan. Namun kendala yang ada yaitu kurangnya partisipasi aktif dari kelompok masyarakat dengan pendidikan tinggi (sarjana) dan kurangnya motivasi terhadap program tersebut.

Studi Uli S. (2018) pada Kelurahan Karangwaru Kota Yogyakarta, menggunakan respon masyarakat di lokasi sebagai data yang diperoleh melalui teknik observasi lapangan, kuesioner, wawancara dan data sekunder. Temuan yang diperoleh menyatakan bahwa masyarakat menilai hasil-hasil implementasi program KOTAKU sudah efektif, terutama variabel penyediaan atas sarana proteksi kebakaran yang dinilai cukup efektif karena keterbatasan jumlah sarana di Karangwaru.

Studi terdahulu milik Widiyanti (2018) yang berlokasi di wilayah Kricak RW 1 Tegalrejo Yogyakarta, menggunakan metode deskriptif kualitatif untuk menganalisis persepsi masyarakat wilayah setempat tentang implementasi program KOTAKU. Data diperoleh melalui wawancara, observasi dan dokumentasi. Hasil penelitian ini mengidentfikasi implementasi Program Kotaku di lokasi penelitian telah berjalan sesuai tujuan program dimana masyarakat menyatakan telah merasakan dampak positif, seperti fisik lingkungan berubah menjadi tidak kumuh, kesadaran masyarakat untuk memelihara lingkungan telah tumbuh, adanya ruang 
terbuka publik, dan peningkatan ekonomi masyarakat setempat melalui pemanfaatan ruang terbuka publik.

Penelitian yang dilakukan saat ini juga bertujuan mengevaluasi tingkat efektifitas pelaksanaan program KOTAKU di wilayah Kota Langsa melalui perspektif masyarakat sasarannya. Data yang dibutuhkan dikumpulkan melalui teknik observasi, kuesioner dan wawancara seperti yang dilakukan oleh para peneliti terdahulu. Pendekatan analisis interaktif digunakan untuk menganalisis data dalam upaya menjawab rumusan masalah penelitian ini.

\section{METODE PENELITIAN}

Lokasi penelitian adalah Kota Langsa meliputi lima kecamatan, yaitu Kecamatan Langsa Kota, Kecamatan Langsa Barat, Kecamatan Langsa Timur, Kecamatan Langsa Baro serta Kecamatan Langsa Lama. Total jumlah desa sebanyak 66 buah.

Metode pengumpulan data adalah penelitian lapangan (field research) yang dilaksanakan secara langsung pada obyek penelitian. Penelitian lapangan dilakukan dengan melakukan observasi, menyebarkan kuesioner, serta melakukan wawancara pada para responden. Responden adalah aparatur pemerintah baik tingkat kecamatan maupun tingkat desa/gampong yang terdapat program KOTAKU yang dilaksanakan Pemerintah Kota Langsa. Jumlah total responden yaitu sebanyak 138 orang, dengan profil yang dirangkum dalam Tabel 1.

Deskriptif kuantitatif digunakan sebagai metode analisis data dengan menjabarkan dan menganalisis hasil-hasil penelitian yang diperoleh. Lima aspek digunakan sebagai standar pengukuran efektivitas dari program KOTAKU (Budiani, 2009; Kristanto, 2013; Siagian, 2014), meliputi: (1) pemahaman program, yaitu derajat pemahaman masyarakat secara umum maupun peserta sasaran secara khusus terhadap kegiatan program; (2) ketepatan sasaran, yaitu sejauhmana pencapaian sasaran antara yang dikehendaki dengan yang terealisasi; (3) ketepatan waktu, yaitu apakah hasil yang dicapai sudah sesuai dengan yang diestimasikan berdasarkan batasan waktu pelaksanaan yang ditetapkan sebelumnya; (4) pencapaian tujuan, yaitu level kesesuaian antar hasil pelaksanaan program yang dicapai dengan tujuan program yang telah ditentukan sebelumnya; serta, (6) pemantauan perubahan, yaitu menilai arah dan besaran dari dampak program terhadap terjadinya perubahan nyata atas kehidupan sosial dan ekonomi masyarakat setempat.

Prosedur penilaian dilakukan dengan mencari nilai rerata persentase atas setiap indikator efektivitas. Penentuan skor dalam pengukuran tingkat efektivitas dijalankan dengan memberikan nilai berupa skala Likert dengan kisaran dari satu sampai empat pada setiap pertanyaan.

\section{Tabel 1. Profil Responden}

\begin{tabular}{clc}
\hline No & \multicolumn{1}{c}{ Keterangan } & Jumlah \\
\hline 1 & Kepala Desa/Gampong di Wilayah Kota Langsa & 66 \\
2 & Sekretaris Desa/Gampong di wilayah Kota Langsa & 66 \\
3 & Camat/Sekretaris Camat di Wilayah Kota Langsa & 5 \\
4 & Dinas Pekerjaan Umum Kota Langsa & 1 \\
\hline & & 138 \\
\hline
\end{tabular}

Sumber: Diolah Penulis, 2020. 
Untuk mengidentifikasi hasil dari level efektivitas terhadap program tersebut maka ditentukan interval kelas sebagai pengukuran, dengan rumus (Widyanti, 2018; Nababan, 2015; Ichsan \& Jannah, 2019):

$$
\text { Interval }(i)=\frac{\text { Nilai Atas }- \text { Nilai Bawah }}{\text { Jumlah Kelas }}
$$

Dikarenakan penggunaan skala Likert berupa skor 1 sampai 4, maka skala penilaian yang diperoleh yaitu 0,75. Dengan demikian, level keputusan atau kriteria pengukuran efektivitas dari program adalah jika nilai antara 1 sampai 1,75 maka program dinilai tidak efektif; jika nilai lebih dari 1,75 sampai 2,5 maka program dinilai kurang efektif; jika nilai lebih dari 2,5 sampai 3,25 maka program dinilai efektif; dan, jika nilai lebih dari 3,25 sampai 4 maka program dinilai sangat efektif.

\section{HASIL ANALISIS}

\section{Program KOTAKU di Kota Langsa}

Program KOTAKU di Kota Langsa dilaksanakan sejak tahun 2016 sampai dengan sekarang. Tujuan utama program ini yaitu peningkatan akses terhadap infrastruktur dan pelayanan dasar pada permukiman kumuh perkotaan serta mendukung perwujudan permukiman perkotaan layak huni, produktif, dan berkelanjutan. Tujuan ini mencakup dua maksud, yaitu memperbaiki akses masyarakat atas infrastruktur dan fasilitas pelayanan pada permukiman kumuh perkotaan; serta upaya meningkatkan kesejahteraan masyarakat di wilayah perkotaan melalui pencegahan dan peningkatan kualitas di permukiman kumuh, berbasis masyarakat, dan derajat partisipasi dari pemerintah daerah.

Program KOTAKU ini terdiri dari dua kegiatan utama yaitu infrastruktur dan kegiatan pemberdayaan ekonomi masyarakat. Data penelitian yang digunakan meliputi periode tahun 2017 sampai 2020, dimana tercatat 64 desa telah mendapatkan program
Kotaku ini baik berupa program perbaikan sarana fisik maupun program pemberdayaan masyarakat. Mayoritas desa ini memperoleh jenis program pemberdayaan masyarakat, seperti kegiatan pelatihan KSM/KPP dalam meningkatkan kompetensi, pelatihan aparatur desa, pelatihan perencanaan partisipatif, pelatihan pengelolaan keuangan desa, ataupun pelatihan ketrampilan. Program ini memiliki tujuan meningkatkan peran serta masyarakat atas pemanfaatan dan pemeliharaan sarana dan prasarana dalam mengurangi wilayah kumuh perkotaan, serta mengupayakan ada perubahan perilaku masyarakat dalam upaya menjaga lingkungan sekitarnya.

Sedangkan untuk program perbaikan infrastruktur hanya beberapa desa saja yang mendapatkannya. Program perbaikan sarana fisik seperti perbaikan jalan desa, perbaikan drainase, pembuatan sumur bor, penyediaan gerobak/bak sampah, pembangunan MCK, hidran umum, pemasangan paving blok, pembangunan, pembangunan instalasi pengolahan air limbah dan lain sebagainya. Tujuan dari program ini yaitu memperbaiki akses masyarakat atas infrastruktur permukiman sesuai dengan $7+1$ indikator kumuh.

\section{Analisis Efektifitas Program KOTAKU}

Penelitian ini dilakukan di wilayah Kota Langsa yang meliputi lima kecamatan. 166 responden yang digunakan dalam penelitian ini mayoritas memiliki rentang usia antara 45 sampai 56 tahun (56 orang atau 33,73\%), serta telah menempuh jenjang pendidikan Strata-1 (75 orang atau 45,18\%).

Aspek-aspek dari standar pengukuran efektivitas dari program KOTAKU meliputi pemahaman program, ketepatan sasaran, ketepatan waktu, pencapaian tujuan, serta pemantauan perubahan (Budiani, 2009; Karauwan et al., 2017; Siagian, 2014). Hasil analisis atas masing-masing aspek efektivitas tersebut diuraikan sebagai berikut. 


\section{Pemahaman Program}

Berdasarkan Tabel 2 diperoleh bahwa kegiatan sosialisasi yang dilakukan pihak pelaksana proram KOTAKU dinyatakan telah efektif dalam memberikan pemahaman kepada masyarakat tentang program ini, dengan nilai rata-rata sebesar 3,01. Kegiatan sosialisasi yang dilakukan pihak pelaksana proram KOTAKU juga dinyatakan telah efektif dalam memberikan pemahaman sehingga masyarakat mengerti maksud dan tujuan dari tentang program ini, dengan nilai rata-rata sebesar 3,16.

Sosialisasi program KOTAKU di Kota Langsa di masyarakat juga dinilai sangat efektif, dengan nilai rata-rata 3,25. Hanya saja, level frekuensi atas kegiatan pemberian pemahaman oleh pihak pelaksana mengenai program KOTAKU di Kota Langsa dinilai relatif masih kurang efektif, dengan nilai ratarata 2,49. Tingkat partisipasi masyarakat di dalam program KOTAKU dinilai telah sangat efektif dalam mengikuti kegiatan sosialisasi program ini dalam mengurangi kawasan pemukiman kumuh yang ada di Kota Langsa, dengan nilai rata-rata 3,29. Tanggapan masyarakat terhadap program KOTAKU di wilayah desa responden secara umum dinilai telah masuk pada kategori efektif, dengan nilai rata-rata sebesar 3,14 .
Secara umum, berdasarkan hasil akhir dalam Tabel 2 dimana diperoleh nilai rata-rata sebesar 3,06, maka dinyatakan bahwa aspekaspek pemahaman program terhadap program KOTAKU di wilayah Kota Langsa telah termasuk kriteria efektif dalam mencapai tujuan-tujuan yang ditetapkan sebelumnya atas program ini.

\section{Ketepatan Sasaran}

Ketepatan sasaran sangat penting dalam melihat apakah suatu program dapat mencapai tujuan diharapkan. Nilai rata-rata efektivitas pada aspek ketepatan sasaran program dirangkum pada Tabel 3.

Pada pernyataan pertama diperoleh bahwa kondisi infrastruktur atau kelembagaan di desa sebelum adanya program KOTAKU dinilai kurang efektif untuk mendukung perekonomian Kota Langsa, dimana nilai rata sebesar 2,31. Dihubungkan pada pernyataan kedua dimana diperoleh nilai rata-rata sebesar 3,10 , maka bisa dinyatakan bahwa program KOTAKU yang dijalankan di Kota Langsa dinilai efektif dalam mengurangi pemukiman kumuh karena sesuai dengan harapan masyarakat yang menginginkan pemukiman tempat tinggalnya layak dan bersih.

\section{Tabel 2. Efektivitas Pemahaman Program atas Program KOTAKU di Kota Langsa}

\begin{tabular}{clc}
\hline No & \multicolumn{1}{c}{ Pernyataan } & Nilai Rata-Rata \\
\hline 1 & Tingkat pemahaman masyarakat terhadap program KOTAKU. & 3,01 \\
2 & Masyarakat mengerti maksud dan tujuan program KOTAKU. & 3,16 \\
3 & Sosialisasi yang dilakukan kepada masyarakat tentang program KOTAKU. & 3,25 \\
4 & Frekuensi kegiatan sosialisasi yang dilakukan terhadap program KOTAKU. & 2,49 \\
5 & Partisipasi masyarakat dalam mengikuti kegiatan sosialisasi program & 3,29 \\
6 & KOTAKU. & 3,14 \\
\hline & Tanggapan masyarakat terhadap program KOTAKU di desa responden. & 3,06 \\
\hline
\end{tabular}

Sumber: Data primer diolah, 2020. 
Tabel 3. Efektivitas Ketepatan Sasaran Program KOTAKU di Kota Langsa

\begin{tabular}{clc}
\hline No & \multicolumn{1}{c}{ Pernyataan } & \multicolumn{1}{c}{ Nilai Rata-Rata } \\
\hline 1 & $\begin{array}{l}\text { Kondisi infrastruktur/kelembagaan di desa sebelum adanya program } \\
\text { KOTAKU. }\end{array}$ & 2,31 \\
2 & $\begin{array}{l}\text { Program KOTAKU yang dijalankan sudah sesuai dengan harapan } \\
\text { masyarakat. }\end{array}$ & 3,10 \\
3 & $\begin{array}{l}\text { Kesesuaian antara anggaran dengan infrastruktur \& kelembagaan yang } \\
\text { terbangun pada Program KOTAKU. }\end{array}$ & 3,01 \\
4 & $\begin{array}{l}\text { Infrastruktur \& kelembagaan yang terbangun dengan Program KOTAKU } \\
\text { dapat meningkatkan kualitas lingkungan yang lebih baik. }\end{array}$ & 3,08 \\
5 & $\begin{array}{l}\text { Program KOTAKU yang dijalankan dapat berpengaruh dalam } \\
\text { menghilangkan pemukiman/lingkungan kumuh di desa. }\end{array}$ & 3,37 \\
6 & Masyarakat mendapatkan manfaat dari program KOTAKU. & 3,04 \\
\hline
\end{tabular}

Sumber: Data primer diolah, 2020.

Tabel 3 menyatakan tingkat kesesuaian antara anggaran dengan infrastruktur dan kelembagaan yang terbangun pada program KOTAKU di Kota Langsa dinilai efektif, dimana nilai rata-rata yang diperoleh sebesar 3,01. Infrastruktur dan kelembagaan yang dibangun melalui program KOTAKU juga dinilai efektif dalam upaya meningkatkan kualitas lingkungan lebih baik, ditunjukkan oleh nilai rata-rata sebesar 3,08. Pernyataan tentang program KOTAKU yang dijalankan juga dinilai berpengaruh relatif efektif dalam menghilangkan permukiman atau lingkungan kumuh di desa, dimana nilai rata-rata yang diperoleh sebesar 3,37. Program KOTAKU juga dinilai secara efektif memberikan manfaat bagi masyarakat desa, dimana nilai rata-rata diperoleh sebesar 3,04.

Secara umum, berdasarkan hasil akhir dalam Tabel 3 dimana diperoleh nilai rata-rata sebesar 2,98, maka dinyatakan bahwa aspekaspek ketepatan sasaran dari pelaksanaan program KOTAKU di wilayah Kota Langsa telah termasuk dalam kriteria efektif untuk mencapai tujuan-tujuan yang telah ditetapkan sebelumnya. Hal ini menggembirakan karena menunjukkan tujuan pemerintah melalui program ini bisa dicapai.

\section{Ketepatan Waktu}

Ketepatan waktu diukur melalui penggunaan waktu dalam pelaksanaan program yang telah direncanakan itu, yaitu apakah telah sesuai dengan yang diekspektasikan sebelumnya. Nilai rata-rata efektivitas pada aspek ketepatan waktu program dirangkum pada Tabel 4.

Berdasarkan Tabel 4 dapat diidentifikasi waktu penyelesaian atas proses perencanaan dari kegiatan infrastruktur dan kelembagaan yang dilaksanakan pada Program KOTAKU sudah dikategorikan efektif, dimana nilai ratarata diperoleh sebesar 3,20. Selanjutnya juga diidentifikasi bahwa waktu penyelesaian atas proses pelaksanaan dari kegiatan infrastruktur dan kelembagaan yang dilaksanakan melalui Program KOTAKU sudah dikategorikan efektif, dimana nilai rata-rata diperoleh sebesar 3,20.

Kesesuaian antara proses pelaksanaan kegiatan infrastruktur dan kelembagaan yang terlaksana pada program KOTAKU dengan perencanaan yang telah dibuat sebelumnya dinyatakan tergolong efektif, dimana perolehan nilai rata-rata 3,23. Lebih jauh, kesesuaian antara proses pengawasan atas kegiatan infrastruktur dan kelembagaan yang terlaksana pada program KOTAKU dengan perencanaan yang telah dibuat sebelumnya dinyatakan 
termasuk kategori sangat efektif, dimana perolehan nilai rata-rata sebesar 3,30. Proses evaluasi atas keberlanjutan program KOTAKU di Kota Langsa dinyatakan tergolong efektif oleh para responden, dimana nilai rata-rata yang diperoleh sebesar 3,23.

Hasil akhir berkenaan dengan aspek ketepatan waktu dari pelaksanaan program KOTAKU di wilayah Kota Langsa, dimana diperoleh nilai rata-rata sebesar 3,22, maka dinyatakan termasuk dalam kriteria efektif.

\section{Pencapaian Tujuan}

Tujuan dari program KOTAKU yaitu peningkatan akses atas fasilitas infrastruktur serta pelayanan dasar pada kawasan kumuh perkotaan sebagai upaya untuk mendukung perwujudan area permukiman perkotaan layak huni, produktif dan berkelanjutan. Nilai ratarata efektivitas pada aspek pencapaian tujuan program dirangkum pada Tabel 5.

\section{Tabel 4. Efektivitas Ketepatan Waktu Program KOTAKU di Kota Langsa}

\begin{tabular}{clc}
\hline No & \multicolumn{1}{c}{ Pernyataan } & Nilai Rata-Rata \\
\hline 1 & $\begin{array}{l}\text { Waktu penyelesaian proses perencanaan kegiatan infrastruktur \& } \\
\text { kelembagaan yang dilaksanakan pada Program KOTAKU. }\end{array}$ & 3,20 \\
2 & $\begin{array}{l}\text { Waktu penyelesaian proses pelaksanaan kegiatan infrastruktur \& } \\
\text { kelembagaan yang dilaksanakan pada Program KOTAKU. }\end{array}$ & 3,14 \\
3 & $\begin{array}{l}\text { Proses pelaksanaan kegiatan infrastruktur \& kelembagaan yang } \\
\text { dilaksanakan pada Program KOTAKU sudah sesuai dengan perencanaan. }\end{array}$ & 3,23 \\
4 & $\begin{array}{l}\text { Proses pengawasan pada kegiatan infrastruktur \& kelembagaan yang } \\
\text { dilaksanakan pada Program KOTAKU sudah sesuai dengan perencanaan. }\end{array}$ & 3,30 \\
5 & Evaluasi keberlanjutan program KOTAKU . & \multicolumn{1}{c}{ Nilai Rata-Rata } \\
\hline
\end{tabular}

Sumber: Data primer diolah, 2020.

Tabel 5. Efektivitas Pencapaian Tujuan Program KOTAKU di Kota Langsa

\begin{tabular}{clc}
\hline No & \multicolumn{1}{c}{ Pernyataan } & Nilai Rata-Rata \\
\hline 1 & $\begin{array}{l}\text { Program KOTAKU bisa mencapai tujuan program yaitu keteraturan dalam } \\
\text { dimensi bangunan/gedung pada desa. }\end{array}$ & 3,67 \\
2 & $\begin{array}{l}\text { Program KOTAKU bisa mencapai tujuan program pada dimensi akses } \\
\text { jalan lingkungan yang baik pada desa. }\end{array}$ \\
3 & $\begin{array}{l}\text { Program KOTAKU bisa mencapai tujuan program pada dimensi akses air } \\
\text { minum yang layak dan berkualitas pada desa. }\end{array}$ \\
4 & $\begin{array}{l}\text { Program KOTAKU bisa mencapai tujuan program pada dimensi } \\
\text { ketersedian drainase Lingkungan yang baik pada desa. }\end{array}$ \\
5 & $\begin{array}{l}\text { Program KOTAKU bisa mencapai tujuan program pada dimensi } \\
\text { ketersediaan pengelolaan air limbah yang baik pada desa. }\end{array}$ \\
$\quad \begin{array}{l}\text { Program KOTAKU bisa mencapai tujuan program yaitu pada dimensi } \\
\text { pengelolaan sampah yang baik di desa. }\end{array}$ & 3,51 \\
\hline & $\begin{array}{l}\text { Program KOTAKU bisa mencapai tujuan program yaitu pada dimensi } \\
\text { ketersediaan ruang terbuka hijau di desa. }\end{array}$ & 3,30 \\
\hline & $\quad$ Nilai Rata-Rata & 3,79 \\
\hline
\end{tabular}

Sumber: Data primer diolah, 2020. 
Tabel 6. Efektivitas Pemantauan Perubahan dari Program KOTAKU di Kota Langsa

\begin{tabular}{clc}
\hline No & \multicolumn{1}{c}{ Pernyataan } & Nilai Rata-Rata \\
\hline 1 & $\begin{array}{l}\text { Perubahan pada dimensi bangunan/gedung lingkungan sekitar dengan } \\
\text { adanya program KOTAKU. }\end{array}$ & 3,19 \\
2 & $\begin{array}{l}\text { Perubahan pada dimensi akses jalan lingkungan sekitar dengan adanya } \\
\text { program KOTAKU. }\end{array}$ & 3,20 \\
3 & $\begin{array}{l}\text { Perubahan pada dimensi akses air minum pada lingkungan sekitar dengan } \\
\text { adanya program KOTAKU. }\end{array}$ & 3,04 \\
4 & $\begin{array}{l}\text { Perubahan pada dimensi drainase lingkungan sekitar dengan adanya } \\
\text { program KOTAKU. }\end{array}$ & 3,35 \\
5 & $\begin{array}{l}\text { Perubahan pada dimensi ketersediaan pengelolaan air limbah sekitar } \\
\text { dengan adanya program KOTAKU. }\end{array}$ \\
6 & $\begin{array}{l}\text { Perubahan pada dimensi pengelolaan sampah sekitar dengan adanya } \\
\text { program KOTAKU. }\end{array}$ & 3,16 \\
\hline 7 & $\begin{array}{l}\text { Perubahan pada dimensi ketersediaan ruang terbuka hijau sekitar dengan } \\
\text { adanya program KOTAKU. }\end{array}$ & 2,80 \\
\hline & $\quad$ Nilai Rata-Rata & 3,16 \\
\hline
\end{tabular}

Sumber: Data primer diolah, 2020.

Hasil analisis mengidentifikasi nilai rata-rata yang diperoleh mengenai pencapaian program KOTAKU dalam mencapai tujuan keteraturan dalam dimensi bangunan/gedung pada desa sebesar 3,67, sehingga dikategorikan sangat efektif. Pencapaian program KOTAKU dalam mencapai tujuan dimensi akses jalan lingkungan yang baik di desa juga dikategorikan sangat efektif, dengan nilai rata-rata sebesar 3,75. Kategori sangat efektif juga diberikan pada pencapaian program KOTAKU atas tujuan akses air minum yang layak dan berkualitas di desa, dengan nilai rata-rata sebesar 3,51.

Selanjutnya, berdasarkan hasil yang dirangkum pada Tabel 5, pencapaian program KOTAKU dalam mencapai tujuan dimensi ketersediaan drainase lingkungan yang baik di desa terkategori sangat efektif, dengan nilai rata-rata sebesar 3,75. Pencapaian program KOTAKU dalam mencapai tujuan dimensi ketersediaan pengelolaan air limbah maupun dimensi pengelolaan sampah yang baik di desa juga terkategori sangat efektif, dimana nilai rata-rata dari masing-masing pernyataan adalah 3,30 serta 3,55. Kategori sangat efektif juga diberikan pada pencapaian program KOTAKU atas tujuan dimensi ketersediaan ruang terbuka hijau (RTH) yang memadai di desa, dengan nilai rata-rata sebesar 3,79.

Hasil akhir berkenaan dengan aspek pencapaian tujuan-tujuan yang telah ditetapkan sebelumnya melalui program KOTAKU yang dilaksanakan di wilayah Kota Langsa dapat dinyatakan termasuk kategori sangat efektif, dimana nilai rata-rata yang dicapai sebesar 3,63.

\section{Pemantauan Perubahan}

Aspek ini digunakan untuk melakukan evaluasi terhadap perubahan-perubahan yang terpantau pada lingkungan sekitar desa di wilayah Kota Langsa melalui keberadaan program KOTAKU, sehingga bisa dinilai apakah program itu sudah terlaksana dengan efektif atau kurang efektif. Nilai rata-rata efektivitas pada aspek pemantauan perubahan program dirangkum pada Tabel 6. 
Berdasarkan Tabel 6 dapat diidentifikasi bahwa perubahan pada dimensi bangunan atau gedung di lingkungan sekitar dengan adanya program KOTAKU termasuk kategori efektif, yaitu nilai rata-rata diperoleh sebesar 3,19. Perubahan pada dimensi akses jalan lingkungan di lingkungan sekitar dengan adanya program KOTAKU juga termasuk kategori efektif, yaitu nilai rata-rata diperoleh sebesar 3,20. Perubahan pada dimensi akses air minum pada lingkungan sekitar dengan adanya program KOTAKU termasuk kategori efektif juga, dimana nilai rata-rata diperoleh sebesar 3,04. Lebih jauh, perubahan pada dimensi drainase lingkungan pada lingkungan sekitar dengan adanya program KOTAKU dimasukkan dalam kategori sangat efektif, karena perolehan nilai rata-rata yaitu 3,35.

Berikutnya, perubahan pada dimensi ketersediaan pengelolaan air limbah pada lingkungan sekitar dengan adanya program KOTAKU termasuk kategori efektif, dimana nilai rata-rata diperoleh yaitu 3,04. Perubahan pada dimensi ketersediaan ruang terbuka hijau (RTH) di lingkungan sekitar dengan adanya program KOTAKU juga termasuk kategori efektif, dimana nilai rata-rata diperoleh sebesar 2,80. Sementara itu, nilai rata-rata diperoleh sebesar 3,39 untuk aspek perubahan dalam dimensi pengelolaan sampah pada lingkungan sekitar dengan adanya program KOTAKU yang dilaksanakan maka termasuk kategori sangat efektif.

Hasil akhir berkenaan dengan aspek pemantauan perubahan dari adanya program KOTAKU yang terlaksana di wilayah Kota Langsa, dengan perolehan nilai rata-rata yaitu 3,16 , maka terkategori dalam kriteria efektif.

\section{Pembahasan}

Kota Langsa merupakan salah satu kota yang sedang berkembang di Propinsi Aceh terasa mulai mengalami kemunculan beberapa kawasan pemukiman kumuh yang harus segera diantisipasi. Sebagai respon atas kondisi tersebut, sejak tahun 2016 program Kota Tanpa Kumuh atau KOTAKU mulai dijalankan di Kota Langsa. Tujuan program KOTAKU yaitu peningkatan akses terhadap fasilitas infrastruktur dan pelayanan dasar di kawasan kumuh.

Analisis efektifitas pelaksanaan program ini diukur menggunakan 5 (lima) dimensi yaitu pemahaman program, ketepatan sasaran, ketepatan waktu, pencapaian tujuan program serta pemantauan perubahan. Efektifitas berfokus pada output suatu kegiatan yang dicapai berdasarkan batasan anggaran biaya, skedul waktu dan jumlah personil yang ada. Pelaksanaan suatu program dinilai efektif jika utput yang dihasilkan semakin memenuhi atau melebihi tujuan yang ingin dicapai (Alam et al., 2017; Garcia-Sanchez et al., 2013; Mihaiu et al., 2010).

Berdasarkan hasil-hasil penelitian ini diperoleh bahwa secara khusus di Kota Langsa, pelaksanaan program Kotaku berada pada angka rata-rata 3,21 atau bahwa pelaksanaan program Kotaku di Kota Langsa ini dinilai efektif dalam mencapai tujuan mengurangi pemukiman kumuh yang ada. Apabila kontribusi output yang dihasilkan program ini semakin besar atas pencapaian tujuan program pada tahun-tahun berikutnya, maka pelaksanaan program KOTAKU di Kota Langsa dalam upaya pengentasan wilayah pemukiman kumuh perkotaan dapat dinyatakan semakin efektif. Hal ini sesuai dengan argumen yang diajukan sejumlah ahli dan peneliti sebelumnya (Widiyanti, 2018; Zuhrya, 2017; Daft, 2012; Sudriamunawar, 2012; Satries, 2011; Cribbin, 2010).

Berdasarkan hasil ini, direkomendasikan dua hal penting. Pertama, agar pemerintah dapat terus berupaya meningkatkan partisipasi masyarakat di dalam pelaksanaan program KOTAKU di Kota Langsa, mulai dari tahap persiapan, perencanaan, pelaksanaan sampai 
pada tahap keberlajutan program sehingga tujuan dari pada program itu sendiri segera terwujud. Kedua, berupaya melakukan usaha yang lebih komprehensif kepada pihak-pihak pemangku kepentingan terutama dalam hal peningkatan anggaran program KOTAKU di masa datang, sehingga cakupan penyelesaian program menjadi semakin meluas dan titiktitik pemukiman kumuh semakin berkurang di Kota Langsa.

Penelitian ini juga mengidentifikasi dua hambatan utama dalam pelaksanaan dalam program KOTAKU di wilayah Kota Langsa. Hambatan utama terkait dengan keterbatasan dana atas biaya pembangunan infrastuktur yang membutuhkan jumlah sangat besar. Dana pembangunan merupakan satu masalah sangat pelik karena keterbatasan ketersediaan anggaran dari negara tentunya mempengaruhi program perbaikan infrastruktur. Seperti ang sementara ini terjadi di Kota Langsa dimana perencanaan program KOTAKU diperkirakan baru terselesaikan setengah bagian dari yang diekspektasikan. Pemerintah sesungguhnya telah berupaya mengantisipasi permasalahan dana tersebut melalui pemberian kebebasan hak bagi BKM untuk mendapatkan dana tambahan dari pihak eksternal lainya, seperti apa yang tertera dalam pedoman umum pelaksanaan program KOTAKU. Namun demikian, perolehan dana dari pihak luar selain pemerintah tentunya bukan sesuatu yang mudah untuk dilaksanakan.

Faktor selanjutnya sebagai penghambat program pemberdayaan KOTAKU di Kota Langsa adalah kesadaran masyarakat, yaitu ketidakkonsisten masyarakat atau masih naik turunnya (fluktuatif) semangat masyarakat untuk bersedia terlibat dalam proses program tersebut. Lebih jauh, persoalan kesadaran ini juga terlihat dari adanya dominasi kelompok tertentu sehingga bisa dinyatakan bahwa pihak yang berperan aktif hanyalah orang itu saja. Porsi keikutsertaan kelompok anak muda juga diidentifikasi masih sangat kurang dalam proses pelaksanaan program KOTAKU. Kemunculan fenomena ini tentu bukanlah hal yang mengejutkan, karena pada dasarnya beberapa kendala yang dihadapi dalam proses pelaksanaan program pemberdayaan ini akan berkaitan dengan derajat partisipasi anggota masyarakatnya. Kesadaran masyarakat sendiri menjadi instrument penting bagi keberhasilan sebuah program pemberdayaan.

\section{SIMPULAN}

Berdasarkan hasil penelitian yang diperoleh pelaksanaan program Kotaku di Kota Langsa melalui empat tahapan. Tahap pertama yaitu tahap persiapan yang meliputi dua kegiatan utama, yaitu sosialisasi Pembentukan/Penguatan TIPP (Tim Inti Perencana Partisipatif). Tahap kedua yaitu perencanaan, dimulai dengan melakukan perumusan kondisi permukiman layak huni pada tingkat desa/gampong yang diinginkan masyarakat di masa mendatang.

Tahap ketiga yaitu tahap pelaksanaan kegiatan baik berupa kegiatan sosial, ekonomi maupun infrastruktur yang harus sesuai dengan perencanaan yang telah disusun dalam dokumen RPLP. Tahap keempat adalah tahap keberlanjutan diartikan sebagai tahap setelah pelaksanaan lapangan dilakukan, meskipun hal ini tidak dapat terjadi dengan sendirinya melainkan harus diupayakan sejak awal proses dari tahapan persiapan, perencanaan dan pelaksanaan di mana di dalamnya ada tahapan monitoring dan evaluasi.

Walaupun terdapat sejumlah hambatan utama dalam pelaksanaan aktivitas atau program KOTAKU, diantaranya masalah keterbatasan dana yang secara khusus dibutuhkan untuk pembangunan infrastruktur serta persoalan kesadaran masyarakat yang fluktuatif, namun pelaksanaan program KOTAKU sampai saat ini di wilayah Kota Langsa dinilai masih berkategori efektif. 
Kondisi riil yang terjadi terkait program ini dinilai menarik untuk diperdalam oleh para peneliti berikutnya yang bisa menghubungkan pada aspek-aspek kehidupan masyarakat yang lebih spesifik.

\section{UCAPAN TERIMA KASIH}

Kami mengucapkan terima kasih kepada Direktorat Riset dan Pengabdian Masyarakat yang telah membiayai kegiatan penelitian monotahun ini melalui dana DRPM Tahun 2020. Artikel ini merupakan bagian hasil dari hibah monotahun tersebut. Terima kasih juga pada Kepala Bappeda Kota Langsa, Kepala Dinas PUPR Kota Langsa c/q Kabid Bina Marga, Koordinator wilayah program KOTAKU Kota Langsa, pihak Kecamatan dalam wilayah Kota Langsa, Pemerintah gampong/desa yang menjadi obyek penelitian, serta Ketua BKM (Badan Keswadayaan Masyarakat) gampong/desa, dimana telah bekerjasama secara baik selama kegiatan penelitian ini.

\section{REFERENSI}

Alam, M. R., Kitenge, E., \& Bedane, B. G. (2017). Government effectiveness and economic growth. Economics Bulletin, 37(1), 222-227. Retrieved from https://www.researchgate.net/publicatio n/312945627_Government_Effectivene ss_and_Economic_Growth.

Anggara, S., \& Sumatri, I. (2016). Administrasi pembangunan: Teori dan praktik. Pustaka Setia.

Brelsford, C., Martin, T., Hand, J., \& Bettencourt, L. M. A. (2018). Toward cities without slums: Topology and the spatial evolution of neighborhoods. Science Advances, 4(8), 1-8. doi: 10.1126/sciadv.aar4644.

Budiani, N. W. (2009). Efektivitas program penanggulangan pengangguran karang taruna "EKA TARUNA BHAKTI" Desa Sumerta Kelod Kecamatan Denpasar Timur Kota Denpasar. INPUT
Jurnal Ekonomi dan Sosial, 2(1), 49-57. Retrieved from https://ojs.unud.ac.id/ index.php/input/article/view/3191.

Cribbin, J. (2010). Kepemimpinan mengefektifkan strategi organisasi. PT. Pustaka Binaman Pressindo.

Daft, R. L. (2012). Manajemen. Alihbahasa: Edward Tanujaya \& Shirly Tiolina. PT. Salemba Empat.

Garcia-Sanchez, I. M., Cuadrado-Ballesteros, B., \& Frias-Aceituno, J. (2013). Determinants of government effectiveness. International Journal of Public Administration, 36(8), 567-577. doi: 10.1080/01900692.2013.772630.

Ichsan, N., \& Jannah, R. R. (2019). Efektivitas penyaluran dana ZIS: Studi kasus pada SMA Terbuka binaan LAZ Sukses Kota Depok. Al-Falah: Journal of Islamic Economics, 4(1), 86-99. doi: 10.29240/alfalah.v4i1.775.

Karauwan, N. M., Laloma, A., \& Tampongangoy, D. L. (2017). Efektivitas pelaksanaan program pengembangan UKM di Dinas Koperasi dan Usaha Mikro, Kecil dan Menengah Kota Manado. Jurnal Administrasi Publik, 3(46), 1-11. Retrieved from https:// ejournal.unsrat.ac.id/index.php/JAP/arti cle/view/16293.

Mihaiu, D. M., Opreana, A., \& Cristescu, M. P. (2010). Efficiency, effectiveness and performance of the public sector. Romanian Journal of Economic Forecasting, 13(4), 132-147. Retrieved from https://www.researchgate.net/publi cation/227489762_Efficiency_Effective ness_and_Performance_of_the_Public_ Sector.

Nababan, D.R.N. (2015). Efektivitas program pelayanan sosial anak korban bencana oleh Yayasan Kelompok Kerja Sosial Perkotaan (KKSP) di Desa Kutambelin Kecamatan Namanteran Kabupaten Karo. Skripsi (tidak dipublikasikan). Departemen Ilmu Kesejahteraan Sosial Fakultas Ilmu Sosial dan Ilmu Politik Universitas Sumatera Utara. Retrieved from https://docplayer.info/63330602- 
Dewi-riris-natalia-nababan.html.

Pedoman Program Kota Tanpa Kumuh (KOTAKU). (2016). Kementerian Pekerjaan Umum dan Perumahan Rakyat Direktorat Jenderal Cipta Karya.

Sari, A. C. P. (2018). Analisis implementasi pembangunan partisipatif dalam program kota tanpa kumuh (KOTAKU) studi komparatif: Desa Bligo Kecamatan Candi dan Desa Jiken, Kecamatan Tulangan, Kabupaten Sidoarjo, Jawa Timur. Equilibrium: Jurnal EkonomiManajemen-Akuntansi, 14(2), 57-70. doi: 10.30742/equilibrium.v14i2.452.

Satries, W. I. (2011). Efektivitas pemberdayaan pemuda pada organisasi kepemudaan Al Fatih Ibadurrohman Kota Bekasi. Tesis (tidak dipublikasikan). Program Pasca Sarjana Universitas Indonesia. Retrieved from https://docplayer.info/ 39458070-Universitas-indonesiaefektivitas-program-pemberdayaanpemuda-pada-organisasi-kepemudaanal-fatih-ibadurrohman-kota-bekasitesis.html.

Sekaran, U., \& Bougie, R. J. (2016). Research methods for business: A skill building approach ( $7^{\text {th }}$ Edition). Wiley.

Siagian, S. P. (2014). Administrasi pembangunan: Konsep, dimensi dan strateginya. Bumi Aksara.

Steers R. M. (2005). Efektivitas organisasi. Edisi Terjemahan. Erlangga.

Sudriamunawar, H. (2012). Pengantar studi administrasi pembangunan. CV Mandar Maju.

Surat Keputusan Walikota Kota Langsa No. 324/413/2016. Kota Langsa.

Uli S., E. M. (2018). Evaluasi program kota tanpa kumuh (KOTAKU) di Kelurahan Karangwaru, Kecamatan Tegalrejo, Yogyakarta. Skripsi (tidak dipublikasikan). Perencanaan Wilayah dan Kota Universitas Gadjah Mada. Retrieved from http://etd.repository.ugm.ac.id/pe nelitian/detail/160286.
UU RI Nomor 1 Tahun 2011 tentang Perumahan dan Kawasan Permukiman. Jakarta.

http://kotaku.pu.go.id.

Widiyanti, I. (2018). Implementasi program KOTAKU dalam menyelesaikan persoalan lingkungan kumuh di Kricak Yogyakarta. Skripsi (tidak dipublikasikan). Program Studi Pengembangan Masyarakat Islam Fakultas Dakwah dan Komunikasi Universitas Islam Negeri Sunan Kalijaga. Retrieved from https://docplayer.info/125210099Implementasi-program-kotaku-dalammenyelesaikan-persoalan-lingkungankumuh-di-kricak-yogyakartaskripsi.html.

Yusuf, A. M. (2015). Metode penelitian: Kuantitatif, kualitatif \& penelitian gabungan. Kencana.

Zuhrya, A. (2017). Peranan program kota tanpa kumuh (KOTAKU) sebagai media pendidikan sosial untuk meningkatkan keberdayaan ekonomi (Studi kasus pada masyarakat marginal di Desa Putih Kecamatan Gampengrejo Kabupaten Kediri). Skripsi (tidak dipublikasikan). Jurusan Pendidikan Ilmu Pengetahuan Sosial Fakultas Ilmu Tarbiyah dan Keguruan Fakultas Islam Negeri Maulana Malik Ibrahim. Retrieved from https://www.google.com/url?sa=t\&rct=j $\& \mathrm{q}=\&$ esrc $=\mathrm{s} \&$ source $=$ web $\& \mathrm{~cd}=\& \mathrm{cad}=\mathrm{r}$ ja\&uact $=8 \&$ ved $=2$ ahUKEwjQorKRtOfu AhXDXCsKHW61DS0QFjABegQIAh AC\&url=http $\% 3 \mathrm{~A} \% 2 \mathrm{~F} \% 2$ Fetheses.uinmalang.ac.id\%2F9809\%2F1\%2F131300 15.pdf\&usg=AOvVaw2qTiiqQWt2Z2T $8 \mathrm{Nn} 4 \mathrm{eElfl}$. 